\title{
Performance, development and use of Romanov in France
}

\author{
G. RICORDEAU, L. TCHAMITCHIAN and J. P. POIVEY \\ I.N.R.A. - Station d'Amélioration Génétique des Animaux, \\ P.B. 27 - 31326 - Castanet Tolosan Cedex, France
}

\begin{abstract}
The Romanov (R) breed was imported to France in 1963. In 1987, there were 15000 purebred and $80000 \mathrm{~F} 1$ ewes. The ewes have a high precocity and good adaptability to breeding season changes. Litter size (LS) is about 2.2 at 18 months and over 3 in adults, resulting from a high ovulation rate (OR) and a reduced embryonic mortality (EM). OR is less variable, but LS as variable as in other breeds. There are $0.8-1.9 \%$ freemartins.

In ewe lambs, the heritabilities of OR, EM and LS are $0.39,0.09$ and 0.02 , resp. R has a favourable direct effect on lamb viability. Heterosis is high on fertility in ewe lambs, but less on OR and LS, favourable on lamb viability. The lack of performance regression from F1 to F4 in crosses with Berrichon du Cher has allowed the creation of a composite line (INRA 401), used on farms. Ewes suckle a maximum of twins. Lambs grow fast but have a low carcass and meat quality.

A good viability of crossbred lambs and a good productivity of F1 ewes have been observed both in intensive and extensive conditions. In extensive system, $\mathbf{R}$ ewes are relatively susceptible to gastro-intestinal parasitism but are resistant to hepatic or pulmonary parasitism. R lambs seem to be susceptible to caseous lymphadenitis.

Favourable results have been obtained with regard to prolificacy of F1 or 1/4 R ewes and viability of lambs in six other European countries, but an unfavourable effect of heavy summer heat on male activity and female fertility. Composite lines have been created in Spain and Hungary.
\end{abstract}

Index words: Romanov, precocity, litter size, ovulation rate, embryonic mortality, lamb viability, Berrichon du Cher, heterosis, composite line

\section{I - Situation in France}

Romanov (R) breed was introduced to France in 1963 (43). In 1987, there were 15000 purebred ewes among which 4000 registered to UPRA (Unité de Promotion de Race) in 54 flocks, raised in different breeding systems.
These different systems are: 1) permanently outdoors, principally mated in autumn (Sept. to Dec.); 2) outdoors and indoors, principally mated in autumn with about $20 \%$ of matings out of this period; 3 ) principal mating early in the season (Aug. to Oct.) and second mating in autumn (Nov. to Jan.); 4) ac- 
celerated lambing rhythm with 3 or 4 lambing periods per year.

\section{II - Reproduction}

\section{1) Fertility}

$\mathrm{R}$ is characterized by early sexual maturity, long sexual season $(16,31,61)$, good postpartum ovarian and sexual activity in AprilMay, with minimum silent ovulations (48), post partum interval of 36 days in season (58). Good performances are achieved in a system of 3 lambings in 2 years with synchronization of oestrus, with or without PMSG in season $(14,30)$.

\section{2) Litter size and its component}

Examples concerning flocks from different breeding systems (1981 to 1986) are given in table 1. The average litter size (LS) is maximum in system 1 (3.11) and at minimum in system $4(2,55)$. In all these systems, LS varies from 1 to 5 (less than $2 \%$ have LS of 6).

LS is the result of a high ovulation rate (OR) and a reduced embryonic mortality (EM), (45, 46; table 2 and 3). OR is less variable in $\mathrm{R}$ ewes than in Finn ewes $(\mathrm{CV}=20$ to $24 \%$ vs 33 to $37 \%$ ) but LS is as variable as in the other breeds $(\mathrm{CV}=30$ to $34 \%)$ (2).

The high OR of $\mathrm{R}$ ewes results from a more numerous population of recruitable follicles, together with a normal selection through atresia during the late follicular phase. On the contrary the high OR of the Finn ewes results from a markedly reduced incidence of selection through atresia $(18,19)$,

The mechanisms controlling OR are already present at 3-5 months of age (17).

\section{3) Genetic parameters of LS and its components (550 $R$ ewes) (45):}

\begin{tabular}{l|ccc} 
& OR & $\%$ EM & LS \\
\hline Repeatability (inter-year) & 0.30 & 0.07 & 0.12 \\
Heritability $\left(\mathrm{h}^{2}\right)$ & 0.39 & 0.09 & 0.02
\end{tabular}

\section{4) Frequency of freemartinism: $(34,35)$}

2 to $3 \%$ of infertile ewe-lambs

0,8 to $1,9 \%$ of freemartin (some are fertile) in 125 females of mixed litters.

\section{5) Number of ovarian follicles at birth and at 4 weeks old}

The difference between $\mathrm{R}$ and Ile de France (IdF) was significant at birth but not at 4 weeks. At birth, the number of growing follicles is 58 in R (7\% of antral follicles) compared to 337 (26\% of antral follicles) in IdF lambs. At 4 weeks of age, atresia of antral follicles has appeared only in IdF and not in R lambs. Retardation of follicular development together with retardation in the establishment of ovarian sensitivity to gonadotrophins are typical features of $\mathrm{R}$ lambs ovaries during the post-natal period (54).

\section{6) Gonadotrophin plasma levels}

In young males the mean levels of $\mathrm{LH}$ and FSH are at maximum between 6 and 8 weeks.

In ewe-lambs, pituitary FSH concentration at birth is higher in $\mathrm{R}$ than in Berrichon du Cher (BC) or crossbreds (36). The level of FSH was maximum at 3 weeks, and at much higher level than in Lacaune, and significantly higher than in males $(44,28,29)$. The prepuberal plasma level of FSH is highly heritable, but not correlated with OR at the two first matings (2).

\section{7) Testis growth and male fertility}

Testis diameter of $\mathbf{R}$ lambs are not higher than in crossbred lambs, when compared at the same age ( 50 to 100 days), although the latter have much heavier body weight (42).

Daily production of semen in rams of 18 months of age was lower in $\mathrm{R}$ than in IdF. This difference between the two breeds corresponds to a lower total number of Sertoli cells in the $R$ at 3 months of age $(26,27)$. However, the daily production of semen of the 
Table 1. Litter size of Romanov ewes in 4 systems of reproduction: Distribution of LS and influence of age at lambing.

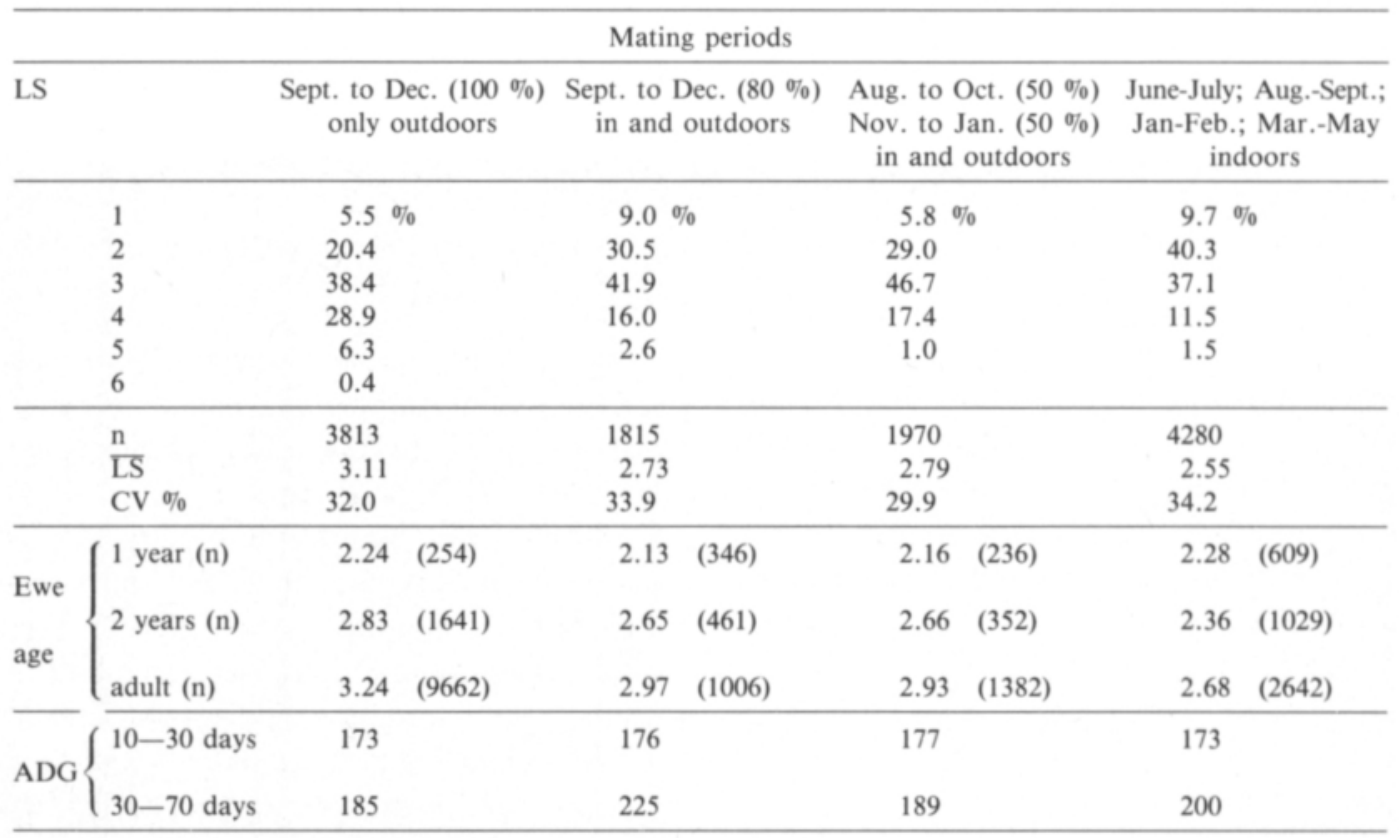

$\mathrm{n}=$ No. of lambings. $\quad \mathrm{ADG}=$ Average daily gain of lambs in $\mathrm{g}$.

Table 2. Distribution of ovulation rate in Romanov and Finn ewes (41).

\begin{tabular}{|c|c|c|c|c|c|c|}
\hline \multirow{2}{*}{$\frac{\mathrm{OR}}{1}$} & \multicolumn{4}{|c|}{ Romanov } & \multicolumn{2}{|c|}{ Finn } \\
\hline & 0.7 & 0.6 & 0.8 & & 1.0 & 1.9 \\
\hline 2 & 34.7 & 7.1 & 12.6 & 1.4 & 32.5 & 13.3 \\
\hline 3 & 55.0 & 60.5 & 56.5 & 16.9 & 39.3 & 36.1 \\
\hline 4 & 8.8 & 28.2 & 27.6 & 45.1 & 19.0 & 26.9 \\
\hline 5 & 0.5 & 3.6 & 2.0 & 28.2 & 6.4 & 13.6 \\
\hline 6 & 0.2 & & 0.4 & 8.4 & 1.4 & 4.1 \\
\hline 7 & & & & & 0.3 & 1.6 \\
\hline 8 & & & & & & 1.6 \\
\hline 9 & & & & & & 0.9 \\
\hline $\bar{x}$ & 2.74 & 3.27 & 3.19 & 4.25 & 3.03 & 3.69 \\
\hline$\sigma$ & 0.66 & 0.67 & 0.72 & 0.88 & 1.00 & 1.38 \\
\hline CV \% & 24.1 & 20.5 & 22.4 & 20.8 & 32.9 & 37.4 \\
\hline $\mathrm{n}$ & 556 & 496 & 246 & 71 & 295 & 316 \\
\hline age & $10 \mathrm{mth}$ & $18 \mathrm{mth}$ & $\begin{array}{l}10 \text { and } \\
18 \mathrm{mth}\end{array}$ & $\begin{array}{l}2 \text { to } 7 \\
\text { years }\end{array}$ & $\begin{array}{c}1.5 \text { to } 3.5 \\
\text { years }\end{array}$ & $\begin{array}{c}>4 \\
\text { years }\end{array}$ \\
\hline
\end{tabular}

Table 3. Litter size obtained at different levels of OR (embryonic mortality \%) (From 41 ).

\begin{tabular}{lllll}
\hline OR & 2 & 3 & 4 & 5 \\
\hline Romanov & $1.90(5 \%)$ & $2.61(13 \%)$ & $3.17(21 \%)$ & $3.58(28 \%)$ \\
Finn & $1.72(14 \%)$ & $2.24(25 \%)$ & $2.63(34 \%)$ & $2.90(42 \%)$ \\
Other & $1.65(17 \%)$ & $2.27(24 \%)$ & $2.48(38 \%)$ & \\
breeds & 1.1 to 2.0 & 1.9 to 2.7 & 1.3 to 3.2 & \\
\hline
\end{tabular}


$\mathrm{R}$ rams is less variable with the season. (15). Concerning the production of ejaculated spermatozoa, a favourable effect on the acceleration of the intensity of collection has been observed (13).

\section{III - Viability of lambs}

Mortality of $R$ lambs increases with increasing LS, but relatively less than in the other breeds. Also, in crossbreeding, $\mathrm{R}$ has favourable direct effect on the viability of the lambs. So for the same birth-type or birth weight, mortality of the lambs is at minimum in $\mathrm{R}$ and intermediate in the crosses (Fig. 1) $(3,44,46$, $49,22,39,63,12$ ).

In the same flock, $\mathrm{R}$ lambs have a better viability in comparison with Finn lambs (10).

\section{Maternal behaviour during the first hours after parturition}

In primiparous ewes, disturbances in licking lambs or acceptance at suckling was less frequent in R (10\%), than in Préalpes du Sud (35\%), or IdF (50\%). Aggressive behaviour was also less frequent in $\mathrm{R}$ ewes (38).

\section{IV - Milk production}

$\mathrm{R}$ ewes have a lower milk production than BC or Lacaune ewes, but they suckle a maximum of twin or triplets, without reducing viability until weaning nor growth after weaning $(10,21,23)$.

\section{V - Carcass quality}

Compared to meat breeds, the carcasses of $\mathrm{R}$ lambs have a bad conformation, a lower proportion of bone, a higher proportion of internal fat, less $\alpha$ fibres and a higher proportion of $\beta$ fibres in the muscle $(1,6,52,59,64)$.

Since 1978, a multibreed testing Station (Berrytest) was created to evaluate the within breed variability and to qualify breeding animals on growth rate and carcass quality (4). The breeding stock of the Berrytest Station
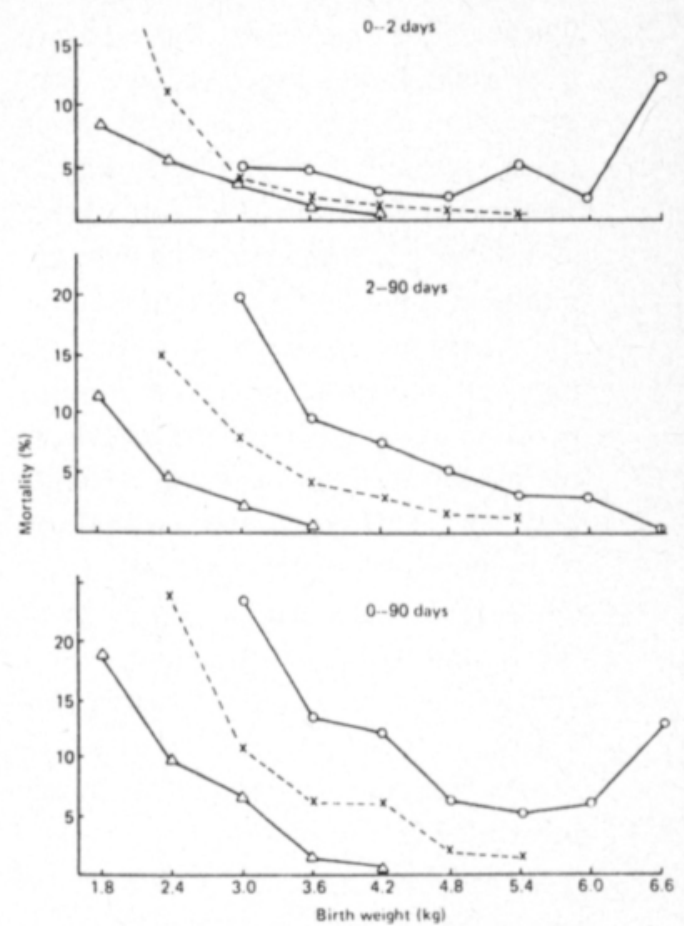

Fig. 1. Mortality of Berrichon du Cher (BC), Romanov (RO) and crossbred $\left(\mathrm{F}_{3}\right.$ to $\left.\mathrm{F}_{4}\right)$ lambs, according to their birth weight: singleton and twins in $\mathrm{BC}$; singletons, twins and triplets in crossbreds: twins and triplets in RO $\mathrm{O}-\mathrm{O}$ BC; $\Delta-\Delta \mathrm{RO} ; \times-\cdots \times \mathrm{F}_{4}$ to $\mathrm{F}_{1}$ (From 39).

consists of $200 \mathrm{R}$ ewes and 750 crossbred $\mathrm{R} \times \mathrm{IdF}$ or $\mathrm{R} \times \mathrm{BC}$ ewes, managed according to a rhythm of 3 lambings in 2 years. In 1986, 496 sires from 9 French meat breeds have been progeny tested through 13825 progeny lambs $(5,6)$.

\section{VI - Resistance to parasitism, caseous lymphadenitis, cold exposure}

1. - Resistance of $R$ ewes to gastro intestinal strongylosis: the results don't show detectable relationship between hemoglobin type and resistance to haemonchus contortus (32).

- Susceptibility to gastro intestinal nematodes: on the Causse of Larzac, the R breed shows a higher natural susceptibility to gastrointestinal nematodes vs Lacaune breed (25). 
- Comparison between $R$, Merinos d'Arles (MA) and crossbreds ewes. The expression of parasitic level, based on faecal egg and larval counts, significantly increases from MA to crossbreed and R for gastrointestinal nematodes, moniezia spp., dictyocaulus filaria, and in contrast, decreases for fasciola hepatica and protostrongylus (mainly neostrongylus linearis). The mecanism of resistance involved seems different between the breeds for the two groups of helminth parasites. $(11,24)$.

- On irrigated grasslands (Camargue), the $\mathrm{R}$ and MA ewes suckling 1 or 2 lambs, have a similar grazing behaviour. However, the $\mathrm{R}$ ewes which are heavier, have less dry matter intake per $\mathrm{Kg}$ of live weight (60).

2. Susceptibility to an experimental Corynebacterium Ps. inoculation.

$\mathrm{R}$ lambs seem to have a greater susceptibility compared to Préalpes du Sud and IdF. They develop most and more severe typical abscesses (37).

3. Concerning the resistance to cold exposure, in condition of transhumance, cf. Vermorel et al. (62).

\section{VII - Utilization of Romanov}

In pure bred: According with flock size or economic situation, about 20 to $40 \%$ of the ewes are mated with $\mathrm{R}$ pure rams to produce replacement. The remainder ones are devoted to industrial crossing.

Crossbreeding with $\mathrm{R}$ allows rapid upgrading of LS to the optimal level of 2.0, either by producing F1 ewes ( 80000 in 1987), or establishing synthetic line, the INRA 401 (57).

1) Production of F1 ewes

Several experiments of crossbreeding between $\mathrm{R}$ and different local breeds have been realized in the INRA flocks and on farms. In all cases, we observe a good viability of crossbred lambs (F1 or born from F1 dams) compared with purebred lambs of local breeds, a favourable heterosis ef- fect on ewe lambs fertility ( $78 \%$ for the F1 R $\times$ Lacaune) (8) and a good adaptation of F1 ewes to extensive conditions.

In accelerated rhythm of reproduction (3 lambings in 2 years).

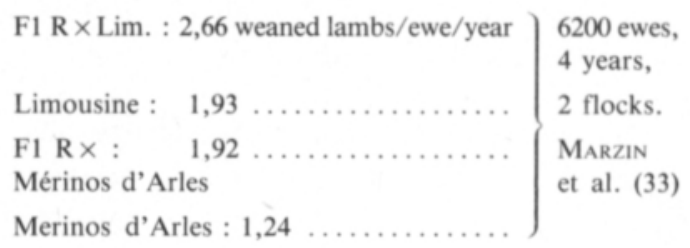

Litter size according to reproductive rhythm (3 lambings in 2 years vs 1 lambing/year)

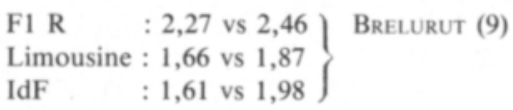

One lambing per year in very extensive conditions (Causses du Larzac and Mediterranean area: 5400 ewes in 12 years): the F1 ewes $(\mathrm{R} \times$ Lacaune and $\mathrm{R} \times \mathrm{MA})$ have a superiority of 0.45 weaned lamb per year vs local breeds (8).

2) The INRA $401(43,47,51)$. This line is selected (in INRA experimental farm, near Bourges) in a specific reproductive system which consists of a first mating at 15 months out of season (April-May) and a second post-partum mating in October of the same year. The results are: fertility 0.86 and 0.82 respectively; LS 1.7 and $1.9 ; \mathrm{h}^{2}$ of fertility 0,06 and 0,03 ; of LS 0,13 and $0,08(39,56)$.

Since 1980, 450 males INRA 401 have been used on farms, to serve a population of about 21000 ewes in 143 flocks (55).

\section{Insertion of the Booroola $(F)$ gene in the $R$ breed}

Since 1986, an experiment was undertaken, for the understanding of mechanisms underlying the regulation of OR. Observations on the F1 lambs concern FSH levels and OR (20, 17,53 ), use of hCG between 3 to 5 months to distinguish lambs carrying or not Booroola gene. 


\section{Conclusion}

With $15000 \mathrm{R}$ ewes, $80000 \mathrm{~F} 1$ ewes and 21000 ewes issued from INRA 401 program, the total population of $\mathrm{R}$ and crossbreds represents about 115000 ewes.

$\mathrm{R}$ breed has been also introduced in Spain, Portugal, Italy, Hungary, Czechoslovakia,
West Germany, and more recently in the Southern Mediterranean countries (Algeria, Tunisia, Egypt, Israël), South Africa and Canada

Acknowledgments. We are grateful to Eric MOREAU, UPRA Finnois-Romanov, for his collaboration.

\section{References}

1. Boccard, R., \& Dumont, B.L., 1986. Evolution possible de la technologie de la viande ovine et conséquences sur la composition (rapport muscle/os) des agneaux. 11è Journ. Rech. Ovine \& Capr., INRAITOVIC: 74-97.

2. Bodin, L. \& ELSEN, J.M., 1988. Variability of natural or induced litter size of French sheep breeds. Génét. Sél. Evol. (in press).

3. Bosc, M.J. \& Cornu, C., 1976. Étude des facteur affectant les conditions de mise bas et la survie des agneaux. 2è Journ. Rech. Ovine \& Capr., INRAITOVIC: $306-321$.

4. Bouıx, J., 1988. Déterminisme génétique des qualités de carcasse des ovins. 3rd World Congr. Sheep \& Beef Cattle Breed. (Paris) 1: 397-413.

5. Bouix, J., Bibe, B. \& Lefevre, C., 1982. Genetic parameters of growth and carcass quality for meatsheep in progeny testing station. Proc. 2nd World Congr. Genet. Appl. Livest. Prod. (Madrid) 8: 732-738.

6. Bouix, J., Bibe, B., Lefevre, C. \& Eychenne, F., 1986. Variabilité génétique entre et intra-race de la croissance et des qualités de carcasses d'agneaux. 11è Journ. Rech. Ovine \& Capr., INRA-ITOVIC: 115-145.

7. Bouix, J., Perret, G. \& Bibe, B., 1986. Genetic improvement of body growth and carcass quality for lambs in France. 36th Ann. Meet. EAAP (Budapest), Summaries 2: 152-153.

8. Bouix, J., Prud'hon, M., Molenat, J., Bibe, B., Flamant, J.C., Maquere, M. \& Jacquin, M., 1985. Potentiel de prolificité des brebis et systèmes de production utilisateurs de parcours. Résultats expérimentaux. 10è Journ. Rech. Ovine \& Capr., INRA-ITOVIC: $252-291$.

9. Brelurut, A., 1987. Productivité d'un troupeau de brebis selon le rythme de reproduction. Bull. Tech. CRZV Theix, INRA (68): 5-10.

10. Bunel, J.C., Lefevre, C. \& Tchamitchian, L., 1975. Performances de reproduction et d'élevage des brebis Finnoises et Romanov en race pure. 1è Journ. Rech. Ovine \& Capr., INRA-ITOVIC 2: 3-17.

11. Cabaret, J. \& Gruner, L., 1988. Genetic variabili-

ty of resistance to parasites. 3rd World Congr. Sheep \& Beef Cattle Breed. (Paris) 1: 577-592.

12. Cabello, G. \& Levieux, D., 1981. Absorption of colostral IgGl by newborn lamb: influence of the length of gestation, birthweight and thyroid function. Res. Vet. Sci. 31: 190-194.

13. Colas, G., Personnic, D., Courot, M. \& OrtavaNT, R., 1975. Influence du rythme de récolte sur la production des spermatozoides chez les jeunes béliers Romanov. Ann. Zootech. 24: 189-198.

14. Cornu, C. \& Cognie, Y., 1984. The utilization of Romanov sheep in a system of integrated husbandry. In: Genetics of Reproduction in Sheep (Eds. R.B. LAND \& D.W. RoBinson), Butterworths: 383-389.

15. Dacheux, J.L., Pisselet, M.R., Blanc, M.R., Hochereau-de Reviers, M.T. \& Courot, M., 1981. Seasonal variations in the testis fluid secretion and sperm production in different breeds of ram. J. Reprod. Fert. 61: 363-371.

16. Desvignes, A., 1971. La race ovine Romanov. Ann. Zootech. 20: 353-370.

17. Driancourt, M.A., Bodin, L., Boomarov, O., Thimonier, J. \& Elsen, J.M., 1988. Potential of hCG for early identification of prolificacy (in press).

18. Driancourt, M.A., Gauld, I.K., Terqui, M. \& WEBB, R., 1986. Variations in patterns of follicle development in prolific breeds of sheep. J. Reprod. Fert. 78: 565-575.

19. Driancourt, M.A. \& Jego, Y., 1985. Follicle population dynamics in sheep with different ovulation rate potentials. Livest. Prod. Sci. 13: 21-33.

20. Elsen, J.M., Cornu, C., Bodin, L., Thimonier, J. \& Boomarov, O., 1988. FSH plasma levels during the post natal period and natural ovulation rate in Booroola $\times$ Romanov females. 3rd World Congr. Sheep \& Beef Cattle Breed. (Paris) 2: 667-669.

21. Flamant, J.C. \& Bonarti, B., 1979. Evaluation des aptitudes laitières des brebis de race pure ou croisées Romanov. Ann. Génét. Sél. anim. 11: 223-240.

22. Flamant, J.C., Jacquin, M. \& Maquere, M., 1977. Quelques aspects génétique de la vitalité chez les ag- 
neaux. 3è Journ. Rech. Ovine \& Capr., INRAITOVIC: 200-211.

23. Flamant, J.C. \& Labussiere, J., 1972. Premières observations sur les aptitudes laitières des brebis de race Romanov. Ann. Zootech. 21: 375-384.

24. Gruner, L., Cabaret, J., Bouix, J. \& Molenat, G., 1987. Comparative susceptibility of Merinos and Romanov sheep to different helminth parasites. WAAVP 12th Conf. (Montreal).

25. Gruner, L., Cabaret, J., Sauve, C. \& Pailhories, R., 1986. Comparative susceptibility of Romanov and Lacaune sheep to gastrointestinal nematodes and small lungworms. Vet. Parasit. 19: 85-93.

26. Hochereau-de Rreviers, M.T., Blanc, M.R., Colas, G. \& Pelletier, J., 1984. Parameters of male fertility and their genetic variation in sheep. In: Genetics of Reproduction in Sheep (Eds. R.B. LAND \& D.W. RoBinson), Butterworths: 301-314.

27. Hochereau-de Reviers, M.T., Monet-Kuntz, C. \& Courot, M., 1987. Spermatogenesis and Sertoli cell numbers and function in rams and bulls. J. Reprod. Fert., Suppl. 34: 101-114.

28. Lafortune, E., Blanc, M.R., Orgeur, P., Pelletier, J., Perreau, C., Terqui, M. \& Hochereau-de Reviers, M.T., 1984. A comparison of the changes in $\mathrm{LH}, \mathrm{FSH}$ and testosterone in spring-born ram lambs of two different breeds. Reprod. Nutr. Develop. 24: 947-952.

29. Lafortune, E., Blanc, M.R., Pelletier, J., Perreau, C., Terqui, M. \& Hochereau-de Reviers, M.T., 1984. Variation in the plasma levels of gonadotrophin and testosterone and in Leydig and Sertoli cell populations between birth and adulthood in Romanov lambs born in spring or autumn. Reprod. Nutr. Develop. 24: 937-946.

30. Lajous, D., 1987. Mesure du taux d'ovulation et de la mortalité embryonnaire chez les brebis Romanov. Thèse Rech. Univ. (Inst. Nat. Polytechn., Toulouse).

31. Land, R.B., Pelletier, J., Thimonier, J. \& Mauleon, P., 1973. A quantitative study of genetic differences in the incidence of oestrus, ovulation and plasma $\mathbf{L H}$ concentration in the sheep. $\mathbf{J}$. Reprod. Fert. 58: 305-317.

32. Luffau, G., Nguyen, T.C., Cullen, P., Vu Thien Khang, J., Bouix, J. \& Ricordeau, G., 1986. Genetic resistance to Haemonchus contortus in Romanov sheep. 3rd World Congr. Genet. Appl. Livest. Prod. (Lincoln) 11: 683-690.

33. Marzin, J., Prud'hon, M., Brelurut, A., Ancevin, J. \& Reboul, J., 1979. Performances de brebis de races locales ou croisées Romanov soumises à un rythme de reproduction accéléré. 5è Journ. Rech. Ovine \& Capr., INRA-ITOVIC: 349-366.

34. Matejka, M., Cribiu, E.P., Chaffaux, S., Schmitt, O. \& Ricordeau, G., 1985. Deux cas de freemartinism chez des moutons Romanov. Génét. Sél. Evol. 17: 419-434.
35. Matejka, M., Cribiu, E.P., Ricordeau, G. \& Chaffaux, S., 1987. Fréquence du freemartinisme chez des agnelles Romanov. Rec. Med. Vét. 163: $635-638$.

36. Mauleon, P. \& Thimonier, J., 1971. Cited in RicorDEAu et al., 1984. Génét. Sél. Evol. 16: 195-210.

37. Pepin, M., Lantier, F., Pardon, P. \& Marly, J., 1988. Breed susceptibility to experimental Corynebacterium pseudotuberculosis infection in lambs. 3rd World Congr. Sheep \& Beef Cattle Breed. (Paris) 1: $646-648$.

38. Poindron, P., Raksanyi, I., Orgeur, P. \& Le Neindre, P., 1984. Comparaison du comportement maternel en bergerie à la parturition chez des brebis primipares ou multipares de race Romanov, Préalpes du Sud et Ile de France. Génét. Sél. Evol. 16: $503-522$.

39. Razungles, J., Tсhamitchian, L., Bibe, B., Lefevre, C., Brunel, J.C. Ricordeau, G., 1984. The performance of Romanov crosses and their merits as a basis for selection. In: Genetics of Reproduction in Sheep (Eds. R.B. LAND \& D.W. RoBinson, Butterworths: $39-45$.

40. Rıcordeau, G., 1982. Aspects génétique de la viabilité des agneaux. 7è Journ. Rech. Ovine \& Capr., INRA-ITOVIC: $37-73$.

41. Rıcordeau, G., 1988. Composantes de la productivité numerique des brebis. Utilisation des races prolifiques. 3rd World Congr. Sheep \& Beef Cattle Breed. (Paris) 2: 567-588.

42. Ricordeau, G., Blanc, M.R. \& Bodin, L., 1984. Teneurs plasmatique en FSH et LH des agneaux mâles et femelles issus de béliers Lacaune prolifique et non prolifique. Génét. Sél. Evol. 16: 195-210.

43. Ricordeau, G., Desvignes, A., Tchamitchian, L., Rastogi, R. \& Lefevre, C., 1976. Amélioration de la productivité des brebis Berrichonnes du Cher (BC) par croisement. I. Productivité numérique des brebis BC, Contentin, Border Leicester, Romanov et de 3 types de F1. Ann. Génét. Sél. anim. 8: 367-389.

44. Ricordeau, G., Pelletier, J., Courot, M. \& Thimonier, J., 1979. Phenotypic and genetic relationships between endocrine criteria and testicular measurements of young Romanov rams and the ovulation rates at 8 months of their half-sisters. Ann. Génét. Sél. anim. 11: 145-159.

45. Ricordeau, G., Poivey, J.P., Lajous, D. \& EYCHENNE, F., 1986. Genetic aspects of ovulation rate and embryo mortality in Romanov ewes. 3rd World Congr. Genet. Appl. Livest. Prod. (Lincoln) 11: $90-93$.

46. Ricordeau, G., Razungles, J., Eychenne, F. \& TChamitchian, L., 1976. Performances de reproduction des brebis Berrichon du Cher, Romanov et croisées. II. Composantes de la prolifité. Ann. Génét. Sél. anim. 8: 25-35.

47. Ricordeau, G., Razungles, J., Tchamitchian, L., 
Lefevre, C. \& Brunel, J.C., 1982. Paramèters phénotypiques et génétiques des caractèrs de croissance et de reproduction des brebis croisées Berrichon du Cher $\times$ Romanov F1 a F4. Ann. Génét. Sél. anim. 14: 327-352.

48. Ricordeau, G., Tchamitchian, L., Eychenne, F. \& Razungles, J., 1976. Performances de reproduction des brebis Berrichon du Cher, Romanov et croisées. I. Activité sexuelle en début de saison et à contre saison. Ann. Génét. Sél. anim. 8: 9-24.

49. Ricordeau, G., Tchamitchian, L., Lefevre, C. \& Brunel, J.C., 1977 a. Amélioration de la productivité des brebis Berrichon du Cher par croisement. IV. Durée de gestation et viabilité des agneaux Berrichons, Romanov et croisées F1, F2 et F3. Ann. Génét. Sél. anim. 9: 219-239.

50. Ricordeau, G., Tchamitchian, L., Lefevre, C. \& BrUNEL, J.C., 1977 b. Différences génétiques de viabilité entre agneaux de bergerie Romanov, Berrichons du Cher, F1 Romanov $\times$ Berrichon et Finnois. 3è Journ. Rech. Ovine \& Capr., INRA-ITOVIC: 189-199.

51. Ricordeau, G., Tchamitchian, L., Lefevre, C., Brunel, J.C. \& Desvignes, A., 1976. Amélioration de la productivité des brebis Berrichonnes du Cher par croisement. III. Performances de reproduction des trois premières générations de brebis croisées entre les races Berrichonnes du Cher et Romanov. Ann. Génét. Sél. anim. 8: 405-419.

52. Ricordeau, G., Tchamitchian, L., Thimonier, J., Flamant, J.C. \& Theriez, M., 1978. First survey of results obtained in France on reproductive and maternal performance in sheep, with particular reference to the Romanov breed and crosses with it. Livest. Prod. Sci. 5: 181-201.

53. Seck, M., Hochereau-de Reviers, M.T., Bodin, L., Elsen, J.M. \& Boomarov, O., 1988. FSH plasma levels during the first three months of life in male lambs carrying or not the $n \mathrm{~F}$ " Booroola prolificacy gene. 3rd World Congr. Sheep \& Beef Cattle Breed. (Paris) 2: 701-703.

54. Sonjaya, H. \& Driancourt, M.A., 1987. Ovarian follicles during infancy in Romanov and Ile de France ewe lambs. J. Reprod. Fert. 8: 241-248.

55. Tсhamitchian, L., 1987. Mise a l'épreuve en ferme de la souche INRA 401. Rapport à la Comm Nat. d'Amélior. Génét., déc. 1987.

56. Tchamitchian, L., Lefevre, C., Brunel, J.C., Bibe, B. \& Ricordeau, G., 1986. Development of a new synthetic prolific line of sheep. 3rd World Congr. Genet. Appl. Livest. Prod. 9: 535-540.

57. Tchamitchian, L., Ricordeau, G., Lefevre, C., Brunel, J.C. \& Lajous, D., 1979. Amélioration de la productivité numerique par croisement. 5è Journ. Rech. Ovine \& Bov. INRA-ITOVIC: 323-348.

58. Tchamitchian, L., Ricordeau, G., Lefevre, C. \& Desvignes, A., 1973. Observations sur l'anoestrus post-partum des brebis Romanov après un agnelage en saison sexuelle. Ann. Zootech. 22: 295-301.

59. Teyssier, J. \& Prud'hon, M., 1982. Evaluation des différences génétique dans l'importance et la répartition du tissu musculaire, entre 25 et 150 jours, sur des agneaux Romanov, Berrichon $\times$ RO, Lacaune $\times$ RO, Charmois $\times$ RO. Ann. Génét. Sél. anim. 14: $353-368$.

60. Theriez, M., Bechet, M. \& Prud'hon, M., 1982. Results published in: J. MAthiEu, 1981, thèse DAA Agron. Mediterr., ENSA Montpellier; P. LAPEY. RONIE, 1982, thèse DEA Agron, Option Zootechn., ENSA Montpellier.

61. Thimonier, J., 1975. Etude de la puberté et de la saison sexuelle chez les races prolifiques et leur croisements avec des races francaises. 1è Journ. Rech. Ovine \& Capr., INRA-ITOVIC: 2 : 18-37.

62. Vermorel, M., Hocquette, J.F. \& Bouix, J., 1985. Recherches sur les aptitudes a la transhumance des différentes races ovines: résistance aux intempéries. 10è Journ. Rech. Ovine \& Capr., INRA-ITOVIC: $292-304$.

63. Villette, Y., Havet, A., Tсhamitchian, L., Morand-Fehr, P., Theriez, M. \& Ricordeau, G., 1984. Viabilité de l'agneau et du chevreau nouveaunés. Poids à la naissance et types génétiques. In: Physiol. et Pathol. perinat. (Jarrige): 309-328.

64. Vigneron, P., Prud'hon, M., Touraille, C., Valin, C., Bouıx, J. \& BıвE, B., 1986. Croissance des agneaux. Types des fibres musculaires et qualité de la viande. Muscle indicateurs. 11è Journ. Rech. Ovine \& Capr., INRA-ITOVIC: 49-73. 